\title{
INFLUENCE OF UNDERHOOD FLOW ON ENGINE COOLING USING 1-D AND 3-D APPROACH
}

\section{ONDŘEJ BOLEHOVSKÝ, JAN NOVOTNÝ}

Czech Technical University in Prague, Faculty of Mechanical Engineering, Technická 4, 16607 Prague 6, Czech Republic

Email: Ondrej.Bolehovsky@fs.cvut.cz, Jan.Novotny@fs.cvut.cz

\section{SHRNUTÍ}

Tato práce se zabývá numerickou simulací kompletního systému chlazení spalovacího motoru (GT-SUITE), která zahrnuje i simulaci proudění v motorovém prostoru pomocí výpočetně nenáročné simulace. Podrobný model spalovacího motoru je rozšíren o model chladicího okruhu a ten je poté spojen se zjednodušeným modelem motorového prostoru, který je pomocí aplikace GT-COOL vytvořen jako 3-D model a poté přeložen do 1-D podoby. Ve dvou ustálených režimech odpovídajících různé rychlosti jízdy vozidla a zatižení motoru byly zkoumány prístupy pomocí 1-D rešení řazení tepelných výměníků a zmíněného 3-D prístupu využívající model motorového prostoru. Tyto simulace prokázaly nevhodnost 1-D přístupu při řešení proudění na tepelných výměnících v motorovém prostoru a pomohly prozkoumat relativně nenáročnou metodu simulace proudění v motorovém prostoru, která umožňuje podchytit vzájemnou interakci mezi modely chladicího systému a spalovacího motoru a problematiku řazení tepelných výměníku v motorovém prostoru.

\section{KLIČOVÁ SLOVA: PROUDĔNÍ V MOTOROVÉM PROSTORU, CHLAZENÍ SPALOVACICH MOTORŮ, CHLADIČ,} KLIMATIZACE, 1-D SIMULACE

\section{ABSTRACT}

This work deals with numerical simulation of complete cooling system of internal combustion engine (GT-SUITE), which also involves the simulation of flow in underhood using the computationally undemanding simulation. A detailed model of the internal combustion engine is extended to a cooling circuit model which is then coupled to a simplified underhood model which is created with the help of GT-COOL application as a 3-D model and afterwards transferred to a 1-D form. The approaches, one using 1-D solution of arrangement of the heat exchangers and the other 3-D approach using the underhood model, were investigated in two steady states corresponding to various vehicle speeds and engine load. These simulations have shown the inappropriateness of 1-D approach when solving the flow in the heat exchangers in the underhood and helped to explore a relatively undemanding method of flow simulation in the underhood, which enables to detect the interaction between the models of the cooling system and the internal combustion engine and the issue of arrangement of the heat exchangers in the underhood.

KEYWORDS: UNDERHOOD FLOW, ENGINE COOLING, RADIATOR, AIR CONDITION, 1-D SIMULATION

\section{INTRODUCTION}

The underhood aerodynamics also affects, apart from thermodynamic equilibrium of the engine and thermal comfort of the vehicle occupants, the external airflow around the vehicle and also influences the drag coefficient of the vehicle. The management of processes connected with cooling of the whole thermodynamic system of the underhood also affects the amount of consumed fuel and oil and the associated amount of emissions released to the atmosphere. Both experimental and numerical methods can be applied for this issue ([7], [8], [9]) . Within the experimental work, the authors mainly engage in measurement of both external and internal flow and the measurement of particular performance characteristics. In numerical simulation, a great attention is paid to the interaction between flow in the underhood and overall airflow around the vehicle ([11], [12], [13], [15]). Furthermore, the entire underhood are being simulated, both using the 1D and 3D simulations. The numerical methods based on CFD simulation prevail within the 3D simulations. Recently, the possibility of combining 1D and 3D method is extending, i.e. by using GT-SUITE program that combines 1D modelling based on knowledge of physical properties of individual finite volumes contained in 
a given assembly and 3D modelling of such assembly ([9], [10]). The combination of these methods enables, with the knowledge of basic physical relations between individual volumes and on the basis of additional discretization, to calculate the overall energy balance. The resultant energy balance is determined as a solution of system of one-dimensional tasks in each element where at each point the validity of basic equations, such as continuity equation, momentum equation and more, must be maintained.

This work deals with the last-mentioned method. The aim of the work is to create a complex model of the underhood. The aim is to study, with the help of $1 \mathrm{D}$ and 3D simulation, not only the impact of the particular rate of discretization and simplification of the given underhood model on the cooling process, but also to focus on regimes related with the balance state of engine during on hot summer months, at low vehicle speeds.

\section{SOLUTION METHOD AND USED SOFTWARE TOOLS - GT-SUITE}

The above mentioned software package GT-SUITE specializes in calculations based on 1-D principle of fluid dynamics and is focused mainly on tasks related to internal combustion engines in broader sense (to the level of the whole vehicle). It is an object-based universal environment that is common to all applications of this software package. The field applicability of this tool ranges from Propulsion Systems via Thermal Management, Multi Body Mechanics, Flow-HydraulicsFriction up to Integrated Systems. The package also contains an extensive library of models and templates including basic components and more advanced models.

\subsection{MODELLING THEORY}

Flow model used in GT-SUITE is based on solving the basic equations of thermodynamics (generally the Navier-Stokes equations), it is the continuity equation and law of conservation of momentum and energy. These equations are solved for each element of discretized model separately, either using the explicit or implicit scheme depending on particular simulation. The set of equations that have to be solved for each element can be written down according to [2] and [4] as follows:

Continuity equation

$\frac{d m}{d t}=\sum \dot{m}$

Law of conservation of energy - explicit solver

$\frac{d(m e)}{d t}=-p \frac{d V}{d t}+\sum(\dot{m} H)-h A_{s}\left(T_{\text {fluid }}-T_{\text {wall }}\right)$
Law of conservation of energy - implicit solver

$$
\begin{aligned}
\frac{d(\rho H V)}{d t}=V \frac{d p}{d t} & +\sum(\dot{m} H)+V \frac{d p}{d t}- \\
& -h A_{s}\left(T_{\text {fluid }}-T_{\text {wall }}\right)
\end{aligned}
$$

Law of conservation of momentum

$$
\begin{array}{r}
\frac{d \dot{m}}{d t}=\frac{d p A+\sum(\dot{m} u)-4 C_{f} \frac{\rho u|u|}{2} \frac{d x A}{D}}{d x}- \\
-\frac{C_{p}\left(\frac{1}{2} \rho u|u|\right) A}{d x}
\end{array}
$$

Where:

$\begin{array}{ll}\dot{m} & \text { Boundary mass flux } \\ \mathrm{m} & \text { Mass of the volume } \\ \mathrm{V} & \text { Volume } \\ \mathrm{p} & \text { Pressure } \\ \rho & \text { Density } \\ \mathrm{A} & \text { Flow area of cross section } \\ \mathrm{A}_{\mathrm{s}} & \text { Heat transfer surface area } \\ \mathrm{e} & \text { Internal energy } \\ \mathrm{H} & \text { Total enthalpy } \\ \mathrm{h} & \text { Heat transfer coefficient } \\ \mathrm{T}_{\mathrm{fllid}} & \text { Fluid temperature } \\ \mathrm{T}_{\text {wall }} & \text { Wall temperature } \\ \mathrm{u} & \text { Velocity } \\ \mathrm{C}_{\mathrm{f}} & \text { Friction coefficient } \\ \mathrm{C}_{\mathrm{p}} & \text { Pressure loss coefficient } \\ \mathrm{D} & \text { Equivalent diameter } \\ \mathrm{dx} & \text { Discretization length } \\ \mathrm{dp} & \text { Pressure differential } \\ \mathrm{dt} & \text { Time step }\end{array}$

Whereby the value of total pressure is generally defined for compressible flow according to Anderson [1] as:

$$
p_{0}=p+\frac{\rho u^{2}}{2}\left(1+\frac{M^{2}}{4}(2-\gamma) \frac{M^{4}}{24}\right)
$$

Where:

$\begin{array}{ll}\mathrm{p}_{0} & \text { Total pressure } \\ \mathrm{p} & \text { Static pressure } \\ \mathrm{M} & \text { Mach number } \\ \gamma & \text { Specific heat ratio }\end{array}$

As already indicated in the previous chapter, the explicit and implicit scheme can be used for solving the aforementioned equations. When using the explicit method the mass flow, density and internal energy are considered as the primary variables and are solved using the above mentioned equations, where the 
values obtained in the preceding step are considered during the calculation. To ensure the numerical stability of this scheme it is necessary to maintain the Courant criterion in choosing the time step, which defines the correlation between the time step and discretization length according to the equation:

$$
\frac{\Delta t}{\Delta x}(|u|+c) \leq 0.8 * m
$$

\section{Where:}

$\begin{array}{ll}\mathrm{m} & \text { Time step multiplier (less than 1) } \\ \Delta \mathrm{x} & \text { Discretization length } \\ \mathrm{c} & \text { Speed of sound }\end{array}$

In the implicit scheme, the mass flow, pressure and total enthalpy are considered as primary variables when solving the equations. The implicit method solves individual elements of the model at one time using the iterative solution of a set of nonlinear algebraic equations. The condition of the calculation is to ensure numerical convergence at each calculation step. The time step is not dynamically determined as in the explicit method but is specified by the user.

For calculations relating to purely internal combustion engine, i.e. combustion, injection, unsteady flow in tubes where the detection of pressure pulses in a short time scale is important, the explicit scheme with a short time step is exclusively used. The implicit scheme is used for simulations where higher frequencies of pressure pulses are not the object of interest and the simulation time is longer. For this reason it is possible to use longer time steps together with the implicit method, which ensures necessary stability of the calculation and shortens the computation time. The condition of using this method is the negligible dynamics of gases in the system and the value of Mach number less than 0.3. The simulations of cooling circuits of the internal combustion engine are a typical example of using this method.

\section{THERMAL MANAGEMENT - THEORY}

GT-SUITE allows for simulations where the systems solved using the explicit and implicit solver are simultaneously solved, the principle of which this work makes use of, as it combines a complex 1D cooling circuit (solved with the help of the implicit method) with a detailed 1D model of the internal combustion engine (solved with the help of the explicit method).

The advantage of interconnection of the cooling circuit model with detailed model of the internal combustion engine is the interaction between these models, both in steady and transient states (heating, etc.). During the interconnection the heat rejected from the internal combustion engine is transmitted into the cooling circuit, which reversely affects the temperature of the cylinder walls (forms a boundary condition) and other components of the internal combustion engine, which reversely affects the calculation of the heat transfer in the internal combustion engine. It is therefore possible to directly optimize the cooling circuit or its particular components and to observe the direct influence on the internal combustion engine itself. Equally significant is the consideration of the underhood flow, which in similar way affects the performance of particular components of the cooling circuit (i.e. heat exchangers). This model shall be described further below.

Our simulated model contains several heat exchangers, fan and lots of tubes for connecting all parts together. For this reason it is necessary to describe the process of calculation of the transferred heat and the way the heat exchanger was implemented into the model. Equations described in this chapter are taken from the GT-Suite manual [2] and [4]. Our simulation used a discretized model of the heat exchanger, which considers both heat capacity of given exchanger and conductivity of the used materials. The temperature of the heat exchanger is determined based on the heat balance between the flowing liquids and the exchanger according to the following equation:

$$
\begin{aligned}
& \frac{d T_{\text {wall }}}{d t}=\frac{Q_{m}+Q_{s}}{\rho V C_{p}}= \\
& =\frac{\left[h A_{s} \Delta T-\frac{2 k A_{s} \Delta T_{w}}{t}\right]_{M}+\left[h A_{s} \Delta T-\frac{2 k A_{s} \Delta T_{w}}{t}\right]_{S}}{\rho V C_{p}}
\end{aligned}
$$

Where:

$\Delta \mathrm{T} \quad$ Temperature difference between liquid and wall

$\Delta \mathrm{T}_{\mathrm{w}} \quad$ Temperature difference between wall and mean wall temperature

k Heat conductivity

$\mathrm{t} \quad$ Wall thickness

V Volume of material

$C_{p} \quad$ Heat capacity of material

The heat transfer coefficient is then determined using the criterion equation defining the calculation of the Nusselt number as:

$N u=C * \operatorname{Re}^{m} * \operatorname{Pr}^{1 / 3}$

Where:

$\mathrm{Nu} \quad$ Nusselt number

Pr Prandtl number

Re Reynolds number

Where coefficients $m$ and $C$ are determined based on knowledge of performance characteristics of given heat exchanger. 


\subsection{FAN MODELLING}

The used model of fan is based on knowledge of the performance characteristics obtained by measurement. Output enthalpy of the fan power input is determined by:

$$
\begin{aligned}
& h_{\text {out }}=h_{\text {in }}+\Delta h_{s} \frac{1}{\eta_{s}} \\
& \dot{W}=\dot{m}\left(h_{\text {in }}-h_{\text {out }}\right) \\
& \Delta h_{s}=c_{p} T_{\text {total_in }}\left[P R^{\frac{\gamma-1}{\gamma}}-1\right] \\
& T_{\text {total_in }}=T_{\text {in }}+\frac{u_{\text {in }}^{2}}{2 c_{p}}
\end{aligned}
$$

Where:

$\Delta \mathrm{h}_{\mathrm{s}} \quad$ Change of isentropic enthalpy

$\eta \quad$ Isentropic efficiency

PR Pressure ratio, static

$C_{p} \quad$ Specific heat of the incoming gas

$\mathrm{T}_{\text {total_in }}$ Inlet total temperature

$\mathrm{T}_{\text {in }}^{\text {total in }}$ Inlet temperature

$\mathrm{u}_{\text {in }} \quad$ Inlet velocity

\subsection{FLOW SIMULATION AND THERMAL CONDUCTION IN TUBES}

Within the simulation, we tried to create an underhood model as complex as possible including the complete control of the cooling process. The model thus contains a great number of tubes and various valves, thermostats and branching. In order to make the designed model the most accurate, it was necessary not only to consider the friction losses in tubes and in various members in the system but also to consider the roughness of internal tubes walls. For this reason, the coefficient of the friction losses for turbulent regime ( $\operatorname{Re}>4000)$ was calculated according to the equation:

$$
c_{\text {froug. }}=\frac{0.25}{\left[2 \log _{10}\left(\frac{1}{2} \frac{D}{\varepsilon}\right)+1.74\right]^{2}}
$$

Where:

D Tube diameter

$\varepsilon \quad$ Size of tube roughness

In the transient area the coefficient of friction losses is calculated using the linear interpolation between laminar and turbulent flow and the coefficient of friction losses for laminar flow is calculated according to the equation:

$$
C_{f}=\frac{16}{R e}
$$

The thermal conduction in tubes is calculated in GT-COOL environment with the help of heat transfer coefficient at a given point, which is calculated for the each time step. For turbulent regime, the Colburn analogy is used, to which applies:

$h_{g}=\frac{1}{2} C_{f} \rho U_{e f f} C_{p} \operatorname{Pr}(-2 / 3)$

Where:

$\mathrm{C}_{f} \quad$ Friction coefficient of smooth pipe

$U_{\text {eff }} \quad$ Effective velocity outside boundary layer

$C_{p} \quad$ Specific heat

The constant value of Nusselt number $\mathrm{Nu}=3.66$ is considered for laminar flow, and for the transient area between $\mathrm{Re}=2000$ 4000 the heat transfer coefficient is linearly interpolated.

\section{COMPLEX COOLING SYSTEM \& ENGINE} 4.1 INTERNAL COMBUSTION ENGINE

The naturally aspirated gasoline engine with the displacement of $1,4 \mathrm{dm}^{3}$ was chosen as a model of the internal combustion engine. In "stand-alone" (of engine itself) simulation of the internal combustion engine without the cooling circuit the imposed boundary condition of cylinder wall temperature is used for the calculation of heat transfer into the engine cylinder structure. In case of simulation with the cooling circuit a special interconnection between the cooling circuit and the material structure of the engine is created, in this case it is created using the simple Finite Element Method (FEM) model of cylinder liner, piston and cylinder head (incl. ports, valves and valves guides). This model is automatically created by entering dimensions into the dialog boxes. Water passages in the block wall and cylinder head are simply created using simple flow components of corresponding geometry, which are connected to the cooling circuit system and thermally interconnected with the material structure of the engine. Apart from the cooling circuit, the heat transfer to a simplified oil circuit of the engine is also detected. Furthermore, the heat released from the engine friction losses, which are calculated using the empirical Chen-Flynn correlation. For the calculation of the heat transfer into the cylinder walls of the internal combustion engine, the Woschni model is used:

$h_{c}=3.26 \cdot B^{-0.2} \cdot p^{0.8} \cdot T^{-0.55} \cdot w^{0.8}$

\section{Where:}

B Cylinder bore [m]

$\mathrm{p} \quad$ Cylinder pressure $[\mathrm{kPa}]$

$\mathrm{T} \quad$ Mean cylinder gas temperature $[\mathrm{K}]$

w Cylinder gas velocity [m/s] 


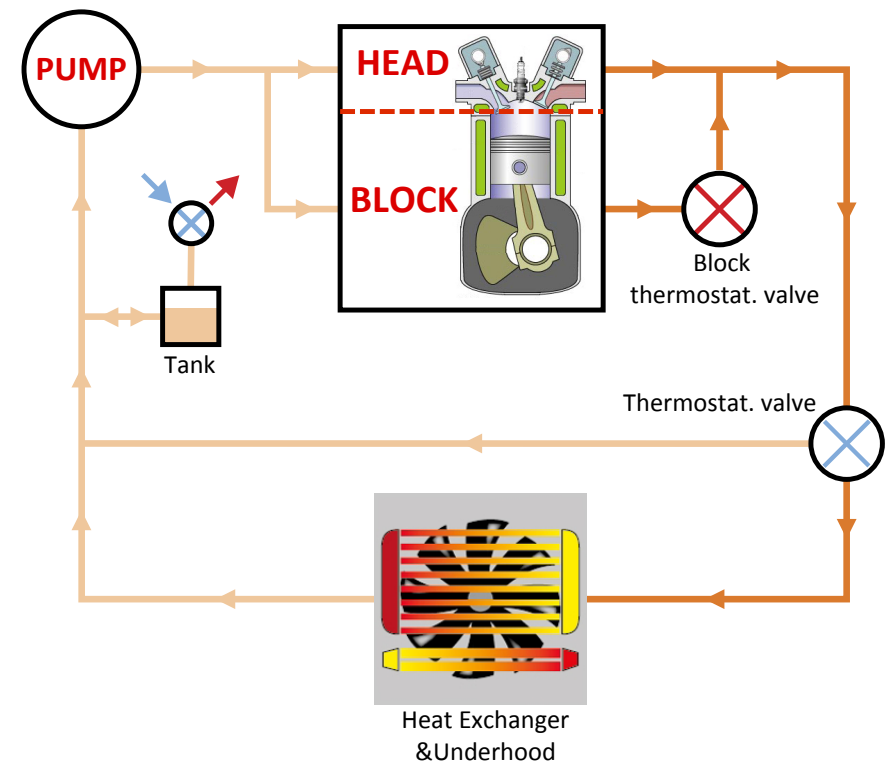

FIGURE 1: Scheme of the cooling circuit OBRÁZEK 1: Schéma chladicího okruhu

\subsection{COOLING CIRCUIT}

The engine cooling circuit includes all important components used in existing internal combustion engines, such as water pump, thermostats, overflow tank with a two-way valve, fan with control. This allows to optimize the individual components with respect to the whole complex system of the internal combustion engine. Simplified diagram of the circuit is shown in Figure 1. In this case, the model also contains the split cooling, which involves separation of cooling of the engine block and cylinder head. The engine block is not being cooled at low coolant temperature (there is additional thermostat in the control circuit) and the coolant flows only through passages of the engine cylinder head. After reaching the desired temperature of the coolant in the engine block, the block is then connected to the whole system and in the next stage the main thermostat connecting the radiator circuit begins to open.

As a heat exchanger/radiator, a suitable performance type according to the parameters of the used engine was chosen from the GT-SUITE library. Other components, such as the pump, thermostats or fan were adjusted according to the size and performance parameters of the engine. In order to reflect the most unfavorable conditions for the cooling circuit on hot summer days, an air-conditioning condenser was positioned in front of the radiator, which transfers the heat to the input airflow from the air-conditioning system. The air-conditioning circuit itself was not modelled. Due to additional power input of the fan electric motor and air-conditioning compressor, these power inputs were brought as a load on the crankshaft and thus a higher heat transfer to the cooling circuit from the cooling loss, which corresponds with the higher load of the engine, was taken into account during the idling state of the engine. The fan was switched in a hysteretic way according to the selected limits $\left(97 \div 90^{\circ} \mathrm{C}\right)$ and its speed set to 2300 RPM according to criterion described in chapter on simulation.

\subsection{UNDERHOOD}

The internal combustion engine together with the cooling circuit in a direct interconnection can be solved using the 1D approach, i.e. all variables are taken as average in the flow cross-section. In this case the flow of the cooling air through engine radiator is taken as a uniform/ideal and the 3D flow issue in the underhood cannot be included. For solving this task the GT-SUITE software package is equipped with a COOL 3D application that allows to model the whole underhood in an simplified way including the heat exchangers and fans in 3D, which allows to include various positions and layering of the heat exchangers and other blockages in the underhood, and detect the spatial distribution of airflow and temperature, see Figure 2 left bottom. This 3D model is then discretized to smaller finite volumes, transferred and then solved using the 1D code in GT-SUITE environment. In our case the discretization was performed using the cubic elements with an edge of $20 \mathrm{~mm}$. The result is the consideration of flow impact in the underhood on the heat exchangers efficiency (according to their arrangement) and the subsequent inclusion of this impact to the aforementioned whole chain: internal combustion engine - cooling circuit - underhood. The underhood envelope forms its own flow-through shape, which has a defined geometric input at its head where ram air effect corresponding to the vehicle speed is being defined, and an
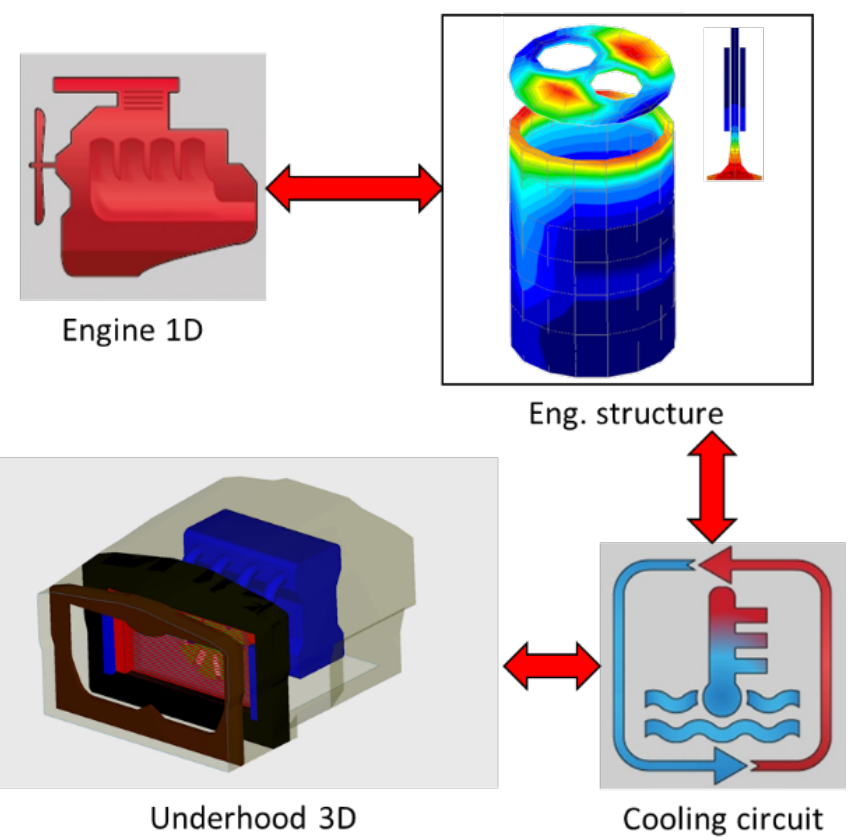

FIGURE 2: Submodels of the system and their linkage OBRÁZEK 2: Jednotlivé modely systému a jejich propojení 
output at the bottom through which the heated air flows out of the underhood. The resultant values of flow rates, pressure, temperature etc. can be reversely displayed again in 3-D space in particular discretized cross-sections of the underhood.

Our work therefore took advantage of all possibilities offered by GT-SUITE for issues connected with cooling of internal combustion engines, furthermore, an interconnection shown in Figure 2 - connection of the internal combustion engine with the cooling circuit (through the material structure) and with 3D underhood model was created. The underhood model was modified in accordance with example files, incl. blockages (mask, frame), selected heat exchanger and fan. A simplified envelope of the internal combustion engine in CAD systems was created and subsequently imported to the GT-SUITE thereby testing also the methodology of transfer of geometric data from CAD systems into this model.

\section{DESCRIPTION AND RESULTS OF SIMULATION}

The created complex model of internal combustion engine with cooling circuit and 3D underhood model was used in our work for "initial" simulations by means of which we could point out the advantage (and also computational complexity) of using this methodology in research in the field of cooling of the internal combustion engines and show the reasons for its usage in future works.

The model is prepared for solving both steady states and also the whole transient operation processes. In steady states, we are interested only in the final state of a given configuration and we do not focus on course of the process after which the system reaches the steady state. This solution allows for quick calculation, because it is not necessary to ensure the numerical convergence of the implicit solver at each step and thus reduce the required number of iterations and also the resultant time consumption of the calculation. The calculation can also be accelerated by the proper selection of the initial conditions (temperature of particular parts, system pressure).

In case of study of the transient operations (engine heating) the initial conditions - mainly temperature - are set to default, usually to the value of the surrounding environment and the simulation runs from these initial conditions. We are interested in the whole course of the transient operation, it is therefore necessary to ensure the numerical convergence of the implicit solver (higher number of iterations) and the whole process is hereby extended (compared to the steady state). The computational complexity is very low due to solving of a comparable issue with the help of CFD.

In our simulations, we focused on those most unfavorable cases where the underhood cooling circuit is exposed to the highest load and there is a risk of overheating of the internal combustion engine in case of improperly designed cooling circuit. The default model was a version without underhood sub-model and without air conditioning. This model was optimized so that under these conditions the overheating of the model was avoided, i.e. the coolant temperature shall not exceed $110^{\circ} \mathrm{C}$. In this regime, the main goal was to compare the design of the engine cooling system with the help of simulation using the 3D flow model of the underhood with the simulation excluding this underhood and using only $1 \mathrm{D}$ approach for flow in the exchangers and their arrangement.

\subsection{UPHILL DRIVING}

The first case of the steady state corresponded to a drive up a steep hill on a hot summer day, with the air conditioning switched on or off. The conditions were set as follows:

- Environment temperature: $35^{\circ} \mathrm{C}$

- Vehicle speed (ram air): $50 \mathrm{~km} / \mathrm{h}$

- Engine load:WOT (wide opened throttle), 4000 RPM

- Fan: 2300 RPM

- Air Condition: $5.5 \mathrm{~kW}$

The resultant values of particular variables are, in this regime, plotted in Figure 3 to 6 , both for 1-D approach without underhood model and for 3-D. Operation with and without air conditioning switched on was another comparative criterion. Figure 3 shows that 1-D approach in this regime is clearly too optimistic and the 3-D variants demonstrate stabilization of the coolant at values about $10^{\circ} \mathrm{C}$ higher. This difference stems from the external mass flow rate through the radiator which is approximately $0.13 \mathrm{~kg} / \mathrm{s}$ lower (Figure 4). The reason is the assumption of an ideal airflow distribution in 1-D case, while the 3-D approach detects deviations connected with size of $A / C$ condenser and its position in relation to the radiator, position and shape of fan and other blockages in the underhood.

Another reason for difference in 1-D and 3-D models is also the modelling of the fan, which in the latter case reaches lower flow rates at significantly higher power input, $0.92 \mathrm{~kW}$ vs. $0.19 \mathrm{~kW}$ - Figure 5. These differences are related to the actual detailed fan model in 3-D and different pressure losses in the assembly of the heat exchangers, which are too optimistic for the 1-D approach. The increased power input of the fan is also subsequently reflected in higher specific fuel consumption of the internal combustion engine, approximately about $3 \mathrm{~g} / \mathrm{kW} . \mathrm{h}$ for both cases (Figure 6).

Figure 7 and 8 are the output from the simulation with the 3-D approach and shows the distribution of the output temperature of the airflow from the $A / C$ condenser and radiator, which are arranged in succession in that order. The figure with the radiator shows a non-uniform heat transfer, e.g. due to lower construction 


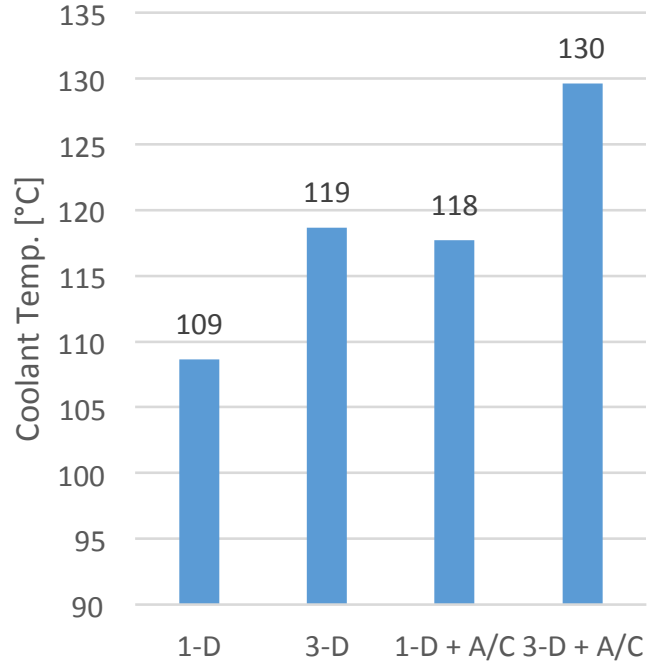

FIGURE 3: Coolant temperature (uphill driving)

OBRÁzek 3: Teplota chladicí kapaliny (jízda do kopce)

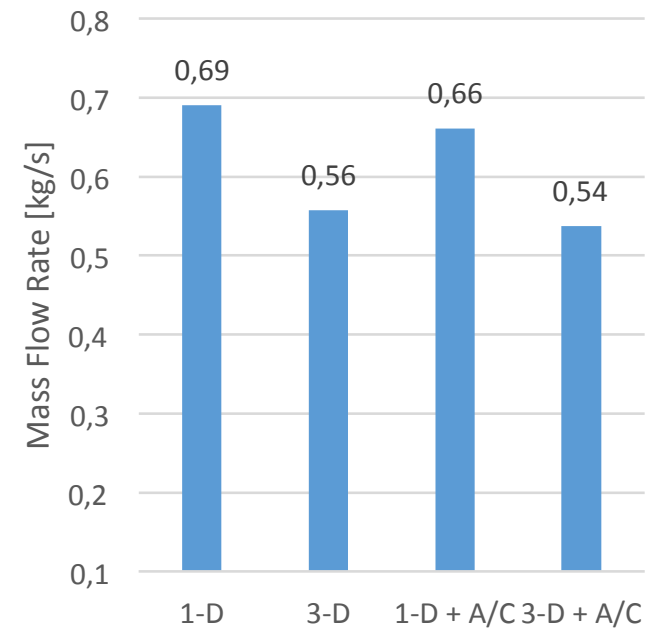

FIGURE 4: External mass flow rate - Radiator (uphill driving) OBRÁZEK 4: Hmotnostní průtok na vnější straně - chladič (jízda do kopce)

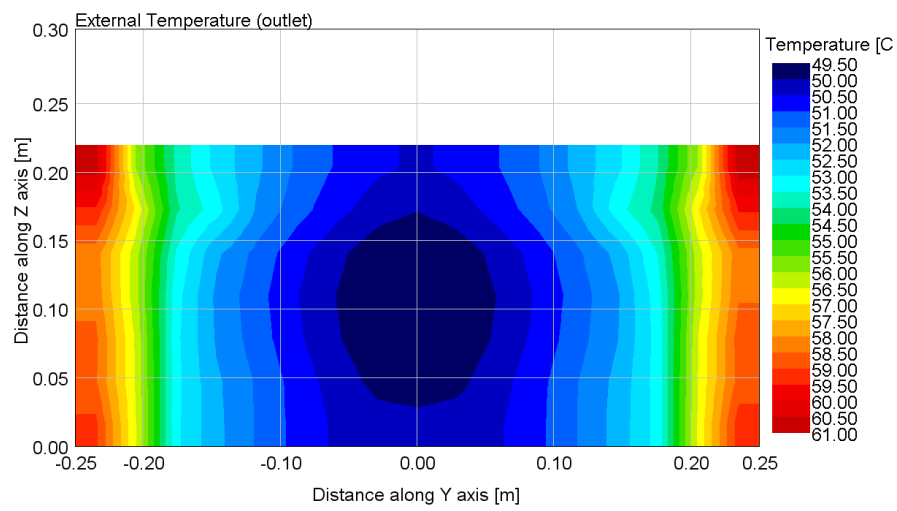

FIGURE 7: External temp. field - A/C Condenser OBRÁZEK 7: Teplotní pole na vnější straně kondenzátoru klimatizace

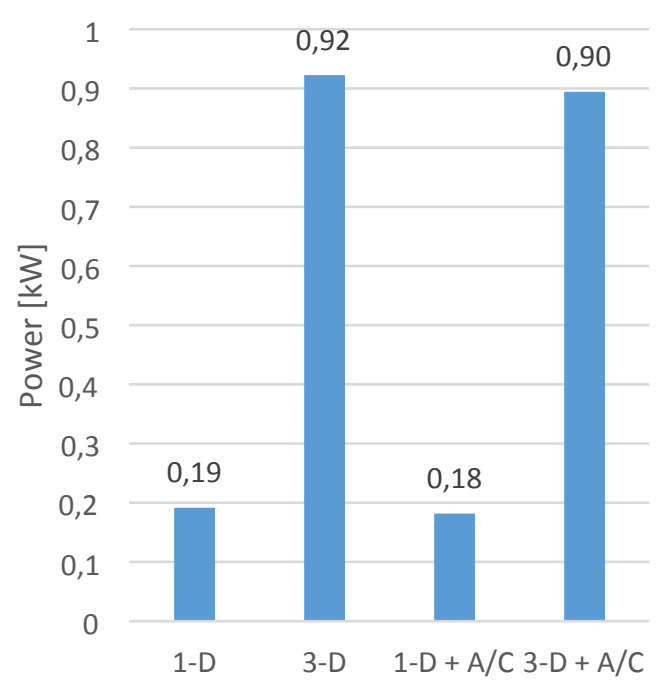

FIGURE 5: Fan power (uphill driving)

OBRÁzEK 5: Príkon ventilátoru (jízda do kopce)

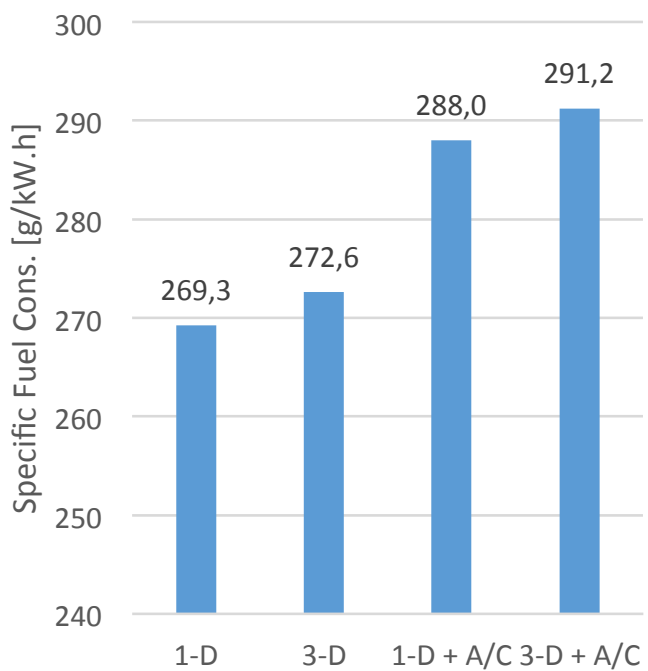

FIGURE 6: Brake specific fuel consumption (uphill driving) OBRÁZEK 6: Měrná spotřeba paliva (jízda do kopce)

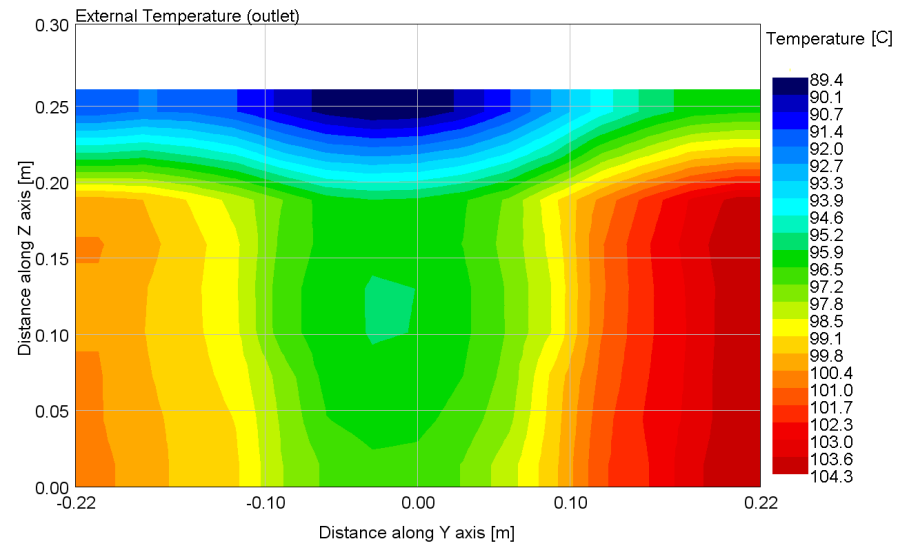

FIGURE 8: External temp. field - Radiator OBRÁZEK 8: Teplotní pole na vnější straně chladiče 
of the $A / C$ condenser where the air flows with higher speed through the upper part of the radiator without added heat from the air conditioning. On the other hand, the figure with condenser detects the velocity field and corresponding airflow heating.

\subsection{ENGINE IDLING}

In another case, we focused on stationary vehicle running at idle on a hot summer day where the air conditioning impact was included again. The conditions were following:

- Environment temperature: $35^{\circ} \mathrm{C}$

- Vehicle speed (ram air): $0 \mathrm{~km} / \mathrm{h}$

- Engine load: idling, 1000 RPM

- Fan: 2300/1800 RPM

- Air Condition: $5.5 \mathrm{~kW}$

In this case there is no stabilized solution due to sufficient cooling performance provided mainly by fan, which causes, with the help of hysteretic switching, a certain periodicity of the process in the cooling circuit. Therefore, the simulation was set as a transient operation with initial conditions close to the expected values, sufficient number of iterations at each step and simulation time of $150 \mathrm{~s}$. The results are thus plotted in time dependence in Figure 9, 10, 11 again for 1-D and 3-D approach involving the impact of the air conditioning switched on. In case of the air conditioning switched on the fan is controlled in two stages: $2300 \mathrm{rpm}$ (radiator) and $1800 \mathrm{rpm}$ (A/C condenser).

In cases without air conditioning, Figure 9 clearly shows periodicity with which the fan can reduce the coolant temperature, and which is around 2 minutes. Again, there is a difference between 1-D and 3-D approach where in case of switched-on fan the temperature decrease of the coolant is slower. It is due to both predicted lower average flow rate in the fan $(0.56 \mathrm{vs} .0 .65 \mathrm{~kg} / \mathrm{s}$, solid line in Figure 10) and also higher power input of the fan (1.18 vs. $0.37 \mathrm{~kW}$, dotted line in Figure 10 ) reflected in higher engine load and the resultant higher heat transfer to the cylinder walls (5 vs. 4 kW, Figure 11).

When switching on the air conditioning the performance of the cooling system decreases and the heat transferred to the engine cylinders increases due to load of engine by the compressor of the air conditioning. However, this will not cause the overheating of the system, the coolant temperature decreases due to the fan, faster in case of 1-D (Figure 9, dashed line), again due to higher predicted flow rate in the fan $(0.54$ vs. $0.62 \mathrm{~kg} / \mathrm{s}$, dashed line in Figure 10). Hence, in the 1-D variant the coolant temperature reaches the value of $90^{\circ} \mathrm{C}$ where the fan switches to a lower speed mode $(2400->1800 \mathrm{rpm})$ in order to allow more heat transfer from the air conditioning condenser. In case of the model with underhood simulation the coolant temperature drops slowly and there is no drop under $93^{\circ} \mathrm{C}$ over $150 \mathrm{~s}$ of the simulation (Figure 9, dashed line).

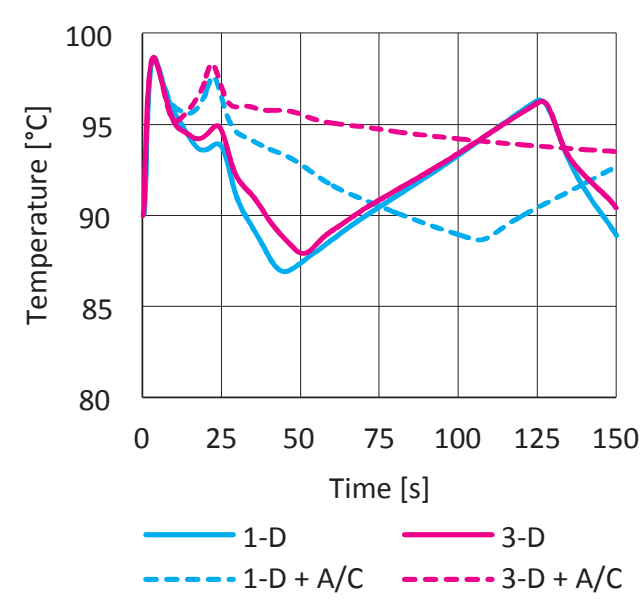

FIGURE 9: Coolant temperature (Engine Idling) OBRÁzEK 9: Teplota chladicí kapaliny (volnoběh)

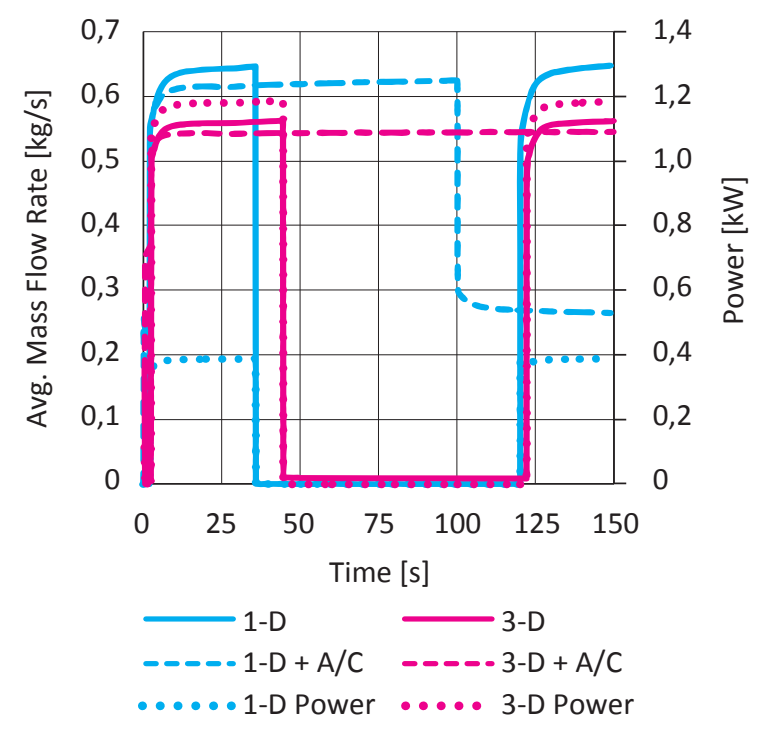

FIGURE 10: Fan mass flow rate and power (Engine idling) OBRÁZEK 10: Hmotnostní průtok a přikon ventilátoru (volnoběh)

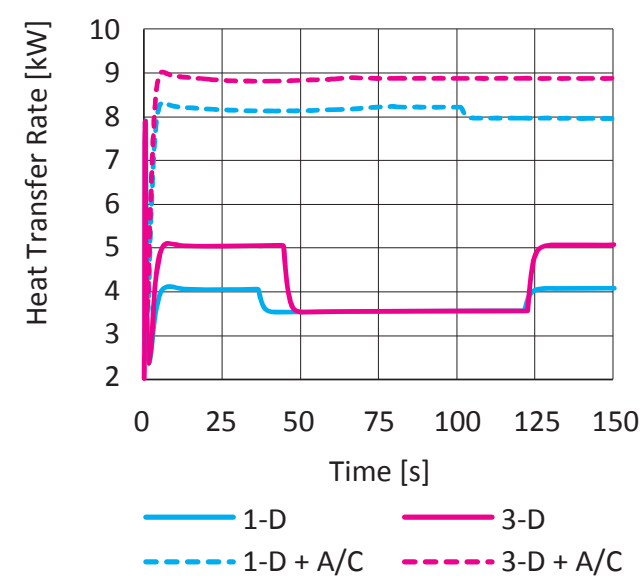

FIGURE 11: In-cylinder heat transfer rate (engine idling) OBRÁZEK 11: Přestup tepla do stěn válce (volnoběh) 


\section{CONCLUSION}

This work deals with methodology of solving the cooling systems of the internal combustion engines in a broader sense, i.e. starting from a detailed 1-D model of the internal combustion engine up to 3-D underhood model reflecting the impact of its shape, position and arrangement of the heat exchangers and the impact of the blockages on the airflow and resultant efficiency of the radiators. For this purpose a commercial GT-SUITE software package was used including the COOL 3D application, which serves for modelling of the 3D underhood and positioning of the radiators, condensers, fans and blocking objects. The transferring of 3D issue to $1 \mathrm{D}$ code and relatively fast calculation is a great advantage.

A model complex cooling circuit of a small naturally aspirated gasoline engine was assembled and subsequently used for initial simulations, in which 3-D approach involving the calculation of flow in the underhood was compared with conventional 1-D approach expecting the distribution of the flowing air on radiators to be uniform. The result of these simulations is the difference in the cooling efficiency of the radiator, which can play a crucial role particularly in regimes with highest load of the cooling system, and lead to improper matching of the radiator. The simulation proved that in steady states of high load and low vehicle speed on a hot day the difference of the coolant temperature can be up to $10^{\circ} \mathrm{C}$ during calculation using both methods, with the fact that the 1-D approach overestimates the cooling performance of the system. Addition of air conditioning condenser in front of the radiator together with added load to the engine from the air conditioning compressor causes additional load of the cooling circuit and increases the coolant temperature. The computation time for one simulated case is in the order of about 3 hours for 3-D approach and 1 hour for 1-D approach, it is particularly influenced by a detailed 1-D model of the internal combustion engine the calculation of which depends on the engine speed. Considering the above, this increase of the computation time is negligible with respect to significant distortion when using only $1-D$ simulation.

Future work should focus on comparison of the experimentally gained data with the current mathematical model and its calibration should be done in order to ensure sufficient accuracy of the simulation.

\section{ACKNOWLED GEMENTS}

This work has been realized using support of:

- The Grant Agency of the Czech Technical University in Prague, grant No. SGS13/184/OHK2/3T/12.

- Technological Agency, Czech Republic, programme Centres of Competence, project \# TE01020020 Josef Božek Competence Centre for Automotive Industry.

- The Ministry of Education, Youth and Sports program
NPU I (LO), project \# L01311 Development of Vehicle Centre of Sustainable Mobility.

This support is gratefully acknowledged.

\section{REFERENCES}

[1] Anderson J. D. (1990). Modern Compressible Flow, McGraw-Hill Publishing Company, New York.

[2] GAMMA TECHNOLOGIES, INC. GT-SUITE Flow Theory Manual, (2014).

[3] GAMMA TECHNOLOGIES, INC. GT-SUITE Cool3D Tutorials, (2014).

[4] GAMMA TECHNOLOGIES, INC. GT-SUITE Cooling Systems and Thermal Management Applications Manual, (2014).

[5] Heywood, J.B., Internal Combustion Engine Fundamentals. (1988). New York, NY: McGraw-Hill,Inc.

[6] Macek, J. (2007). Spalovací motory I., Praha, ČVUT

[7] Pang S., Kalam M., Masjuk, H., Badruddi, I., Hayrat M. (2012). Design Improvements of Engine Cooling System Using CFD and 1D Thermo- Fluid Model: Medium Driving Speed and Keyed-off Conditions. In: Engineering e-Transaction. Vol. 7, No.2, December 2012

[8] Pang S., Kalam M., Masjuki H., Badruddin I., Hayrat M. (2012). A review on air flow and coolant flow circuit in vehicles' cooling system. In: International Journal of Heat and Mass Transfer.

[9] Vdovin A. (2010). Cooling performance simulations in GTSuite. Chalmers University of Technology. Master Thesis 2010.

[10] Klopstein S., Lauer S., Maassen F. (2011). Interpretation tools and concepts for the heat management in the drive train of the future. SAE Technical Paper 2011-01-0650.

[11] Khaled M., Harambat F., Peerhossaini H. (2010). Underhood thermal management: Temperature and heat flux measurements and physical analysis. In: Applied Thermal Engineering. Volume 30.

[12] Sofu T. (2012). Integrated External Aerodynamic and Underhood Thermal Analysis for Heavy Vehicles. U.S. Department of Energy Vehicle Technologies Program Annual Merit Review and Peer Evaluation Meeting.

[13] Lawrence V. (2001). Underhood Airflow Simulation of a Passenger Car Using Computational Fluid Dynamics. SAE Technical Paper 2001-01-3800. 2001

[14] Kumar V., Kapoor S., Arora G., Saha S. et al. (2009). A Combined CFD and Flow Network Modeling Approach for Vehicle Underhood Air Flow and Thermal Analysis. SAE Technical Paper 2009-01-1150.

[15] Farrington R., Rugh J. (2000). Impact of Vehicle AirConditioning on Fuel Economy, Tailpipe Emissions, and Electric Vehicle Range. In: Earth Technologies Forum. Washington, D.C. 